\title{
Ketuban Pecah Dini dan Demam Intrapartum Sebagai Faktor Risiko Sepsis Neonatorum Onset Dini
}

\author{
Naufal Sastra Negara, Setya Wandita, Purnomo Suryantoro \\ Bagian/SMF Ilmu Kesehatan Anak FK-UGM/RSUP Dr. Sardjito, Yogyakarta
}

Latar Belakang. Sepsis neonatorum onset dini masih merupakan penyebab morbiditas dan mortalitas yang penting pada neonatus. Beberapa studi menunjukkan bahwa faktor maternal berhubungan dengan peningkatan risiko sepsis neonatorum onset dini. Faktor-faktor tersebut antara lain adalah ketuban pecah dini dan demam intrapartum.

Tujuan. Untuk mengetahui hubungan antara ketuban pecah dini dan demam intrapartum terhadap peningkatan risiko sepsis neonatorum onset dini

Metode. Penelitian kohort dilakukan secara prospektif selama 2 tahun, antara bulan Januari 2006 sampai dengan Desember 2007 di Instalasi Maternal-Perinatal RS. Dr.Sardjito, Yogyakarta. Neonatus yang terpapar ketuban pecah dini dan/atau demam intrapartum dimasukkan dalam penelitan dan diikuti selama 72 jam. Kriteria eksklusi adalah kelainan bawaan dan/atau lahir dari ibu yang mendapatkan antibiotik intrapartum. Diagnosis sepsis dinilai dalam 72 jam pertama kehidupan berdasarkan kriteria klinis dan konfirmasi biakan positif. Pengukuran hubungan antara paparan dan sepsis ditampilkan dengan risiko relatif (RR) dan interval kepercayaan 95\% (IK 95\%).

Hasil. Didapatkan 5,3\% dari 190 neonatus dengan paparan ketuban pecah dini (RR 1,76; IK 95\% 0,71-4,37), 12,8\% dari 47 neonatus dengan paparan demam intrapartum (RR 4,26; IK 95\% 1,55-11,7), dan 12,9\% dari 31 neonatus dengan paparan ketuban pecah dini yang disertai demam intrapartum (RR 4,31; IK 95\% 1,38-13,5) berkembang menjadi sepsis onset dini secara klinis yang disertai konfirmasi hasil biakan positif. Analisis stratifikasi berdasarkan maturitas kehamilan dan berat badan lahir, diikuti dengan penghitungan menggunakan statistik Mantel-Haenszel, menunjukkan hasil yang tidak berbeda secara bermakna. Meskipun demikian. risiko relatif ketuban pecah dini pada kelompok neonatus cukup bulan dan/atau berat badan lahir cukup tidak meningkat secara bermakna (RR 1,12; IK 95\% 0,44-2,86 dan RR 1,33; IK 95\% 0,57-3,84).

Simpulan. Demam intrapartum merupakan faktor risiko independen sepsis onset dini, sementara ketuban pecah dini meningkatkan risiko secara bermakna pada kelompok neonatus kurang bulan dan berat badan lahir rendah. (Sari Pediatri 2009;10(5):351-6).

Kata kunci: ketuban pecah dini, demam intrapartum, sepsis neonatorum onset dini

Alamat Korespondensi:

dr. Naufal Sastra Negara, Bagian/SMF Ilmu Kesehatan Anak FK-UGM/ RSUP Dr. Sardjito, Jl. Kesehatan no. 1 Yogyakarta. Fakultas kedokteran Universitas Gadjah Mada. Telepon (0274) 587333 psw 301, Fax.: 0274583745. E-mail: naufalsastranegara@yahoo.com 
S epsis neonatorum adalah sindrom klinik akibat respons sistemik terhadap infeksi pada bulan pertama kehidupan bayi. ${ }^{1}$ Onset dini jika manifestasi muncul pada 72 jam pertama kehidupan dan onset lambat jika manifestasi muncul setelah hari ke-4 kehidupan, meskipun lebih sering muncul setelah usia 7 hari. $^{2}$ Insidensi sepsis neonatorum bakterial onset dini di negara maju berkisar 1-4 kasus tiap 1000 kelahiran hidup. ${ }^{3}$ Sedangkan insidens di negara berkembang lebih tinggi 5-8 kali lipat, dengan angka yang pernah dilaporkan berkisar 20-37 kasus tiap 1000 kelahiran hidup. ${ }^{4}$ Sepsis neonatal ditandai dengan onset yang mendadak, manifestasi klinis yang berat dan melibatkan hampir seluruh sistem. ${ }^{5}$ Mortalitas yang pernah dilaporkan mencapai angka 20\%-30\%. ${ }^{6}$ Insidens sepsis meningkat secara bermakna pada neonatus dengan faktor risiko maternal seperti ketuban pecah dini, demam intrapartum, dan amnionitis. ${ }^{3}$

Ketuban pecah lebih dari 18 jam sebelum kelahiran, meningkatkan kemungkinan terjadinya infeksi oleh Streptococcus grup B pada neonatus. ${ }^{7}$ Walaupun terkadang tidak diketahui sumbernya, demam intrapartum telah dihubungkan dengan peningkatan risiko sepsis neonatorum onset dini. ${ }^{8}$ Prematuritas dan berat badan lahir rendah merupakan faktor intrinsik penting sebagai predisposisi sepsis neonatorum onset dini. Meskipun demikian, hasil penelitian yang dilakukan oleh Chacko dan Sohi ${ }^{4}$ menunjukkan bahwa prematuritas dan berat badan lahir rendah yang tidak disertai faktor risiko maternal seperti ketuban pecah dini dan/atau demam intrapatum tidak meningkatkan risiko sepsis onset dini secara bermakna.

Penelitian mengenai faktor risiko sepsis bakterial onset dini di negara-negara maju lebih banyak ditujukan pada kasus Streptococcus grup B (SGB) sebagai patogen utama ${ }^{8-10}$ Sementara penelitian etiologi sepsis onset dini pada neonatus di negara-negara berkembang, seperti India dan Pakistan, menunjukkan jenis patogen yang lebih bervariasi dengan dominasi Escherichia coli. ${ }^{4,6}$ Penelitian bertujuan untuk mengetahui hubungan antara ketuban pecah dini dan/atau demam intrapartum terhadap peningkatan risiko sepsis onset dini.

\section{Metode}

Penelitian menggunakan rancang bangun studi kohort prospektif dengan kelompok pembanding eksternal, dan dipasangkan dengan satu pembanding untuk setiap masing-masing kelompok. Populasi target adalah semua bayi baru lahir yang terpapar ketuban pecah dini dan/atau demam intrapartum. Populasi terjangkau adalah semua bayi baru lahir yang dirawat di Instalasi Maternal Perinatal RS Dr.Sardjito dengan ketuban pecah dini dan/atau demam intrapartum, selama dua tahun dari bulan Januari 2006 sampai dengan Desember 2007. Subjek tidak diikutsertakan jika ibu mendapatkan antibiotik intrapartum atau neonatus menderita kelainan bawaan.

Pengambilan sampel dengan cara consecutive sampling sampai besar sampel terpenuhi. Data diambil dari aspek maternal dan neonatal yang didapatkan melalui anamnesis pada ibu, pemeriksaan fisik pada neonatus, dan pemeriksaan penunjang untuk diagnosis sepsis. Pada aspek neonatus, data dikumpulkan secara prospektif dengan melakukan pengamatan klinis selama 72 jam pertama sejak kelahiran pada kedua kelompok. Penilaian diagnosis sepsis dilakukan berdasarkan kriteria klinis dan konfirmasi kasus dengan hasil biakan darah positif.

Secara klinis diagnosis sepsis neonatorum didasarkan paling sedikit dijumpai satu gejala/tanda pada paling tidak empat kelompok gejala berikut, 1 . Gejala umum bayi tampak sakit, tidak mau minum, kenaikan atau penurunan suhu tubuh $\left(>37,5^{\circ} \mathrm{C}\right.$ atau $<36^{\circ} \mathrm{C}$ pada pengukuran suhu ketiak), sklerema/ sklerederma. 2. Gejala gastrointestinal, muntah atau residu lambung positip, diare, hepatomegali, dan perut kembung. 3. Gejala saluran pernapasan, dispnea, takipnea (pernapasan $>60 \mathrm{x} /$ menit), sianosis. 4. Gejala kardiovaskular takikardia, edema, dan dehidrasi. 5. Gejala sistem syaraf pusat, letargi, iritabel, dan kejang. 6. Gejala hematologi, ikterus, splenomegali, petekie atau perdarahan, leukopenia $\left(\mathrm{AL}<5000 \mathrm{~mm}^{3}\right)$, ratio batang/segmen $\geq 0,2 .{ }^{11}$ Ketuban pecah dini (KPD) adalah ketuban pecah lebih dari 18 jam sebelum terjadi kelahiran. ${ }^{12,13}$ Demam intrapartum (DI) adalah peningkatan suhu lebih dari $38^{\circ} \mathrm{C}$ yang terjadi saat dalam persalinan tanpa ada tambahan definisi. ${ }^{10}$

Semua data penelitian dicatat dalam formulir yang telah disediakan untuk penelitian dan dipindah rekamkan dalam cakram magnetik dengan menggunakan program SPSS versi 10.0. Hasil identifikasi kejadian sepsis neonatorum onset dini disusun dalam tabel $2 \times 2$ untuk menghitung risiko relatif (RR). Analisis dilakukan secara terpisah untuk jenis paparan ketuban pecah dini dan/atau 
demam intrapartum. Analisis stratifikasi dilakukan berdasarkan klasifikasi usia kehamilan dan berat badan lahir, dilanjutkan dengan penghitungan risiko relatif menggunakan statistika Mantel-Haenszel.

\section{Hasil}

Jumlah subjek dengan paparan yang memenuhi kriteria inklusi dan eksklusi selama penelitian pada kelompok dengan paparan 268 neonatus, masingmasing 190 dengan paparan ketuban pecah dini, 47 dengan paparan demam intrapartum, dan 31 dengan paparan ketuban pecah dini yang disertai dengan demam intrapartum. Sementara pada kelompok tanpa paparan didapatkan jumlah subjek keseluruhan 267 neonatus.

Karakteristik dasar variabel maternal dan kelahiran pada kedua kelompok tertera pada Tabel 1. Tidak terdapat perbedaan bermakna pada distribusi data kedua kelompok. Analisis risiko relatif untuk masing-
Tabel 1. Karakterisitik kelahiran dan persalinan pada kedua kelompok

\begin{tabular}{lccc}
\hline \multicolumn{1}{c}{ Variabel } & $\begin{array}{c}\text { Kelompok } \\
\text { dengan } \\
\text { paparan } \\
(\mathrm{N}=268) \\
n(\%)\end{array}$ & $\begin{array}{c}\text { Kelompok } \\
\text { tanpa } \\
\text { paparan } \\
(\mathrm{N}=267) \\
n(\%)\end{array}$ & $\begin{array}{c}\text { Nilai } \\
p^{\mathrm{a}}\end{array}$ \\
\hline $\begin{array}{l}\text { Laki-laki } \\
\text { Usia kehamilan }\end{array}$ & $151(56,3)$ & $128(47,9)$ & 0,05 \\
$<37$ minggu & $118(44,0)$ & $97(36,3)$ & 0,07 \\
Berat badan lahir & $104(38,8)$ & $95(35,6)$ & 0,44 \\
$<2500$ gram & $113(42,2)$ & $96(36,0)$ & 0,19 \\
Cara persalinan & $140(52,2)$ & $11(4,1)$ & \\
$\quad \begin{array}{l}\text { Spontan } \\
\text { Seksiosesaria }\end{array}$ & $15(5,6)$ & $160(59,9)$ & \\
$\begin{array}{l}\text { Pervaginam dengan } \\
\text { tindakan }\end{array}$ & $26(9,7)$ & $29(10,9)$ & 0,66 \\
Asfiksia & $17(6,3)$ & $20(7,5)$ & 0,60 \\
Prosedur invasif & & & \\
\hline a dihitung dengan statistika Chi-Square, bermakna jika \\
$<0,05$
\end{tabular}

Tabel 2. Analisis kelompok dengan masing-masing paparan terhadap sepsis onset dini dengan konfirmasi hasil biakan positif

\begin{tabular}{lccc}
\hline $\begin{array}{c}\text { Insidens sepsis pada kelompok } \\
\text { dengan paparan n/N (\%) }\end{array}$ & $\begin{array}{c}\text { Insidensi sepsis pada kelompok } \\
\text { tanpa paparan n/N (\%) }\end{array}$ & $\begin{array}{c}\text { Risiko relatif } \\
(\text { IK 95\%) }\end{array}$ \\
\hline KPD* $^{*}$ & $10 / 190(5,3)$ & $8 / 267(3,0)$ & $1,76(0,71-4,37)$ \\
$\mathrm{DI}^{* *}$ & $6 / 47(12,8)$ & & $4,26(1,55-11,7)$ \\
KPD dan DI & $4 / 31(12,9)$ & $4,31(1,38-13,5)$ \\
\hline
\end{tabular}

* KPD: ketuban pecah dini ${ }^{* *}$ DI: demam intrapartum

Tabel 3. Analisis stratifikasi berdasarkan maturitas kehamilan dan berat badan lahir

\begin{tabular}{lccc}
\hline Stratifikasi & $\begin{array}{c}\text { RR kelompok } \\
\text { dengan ketuban } \\
\text { pecah dini (KPD) }\end{array}$ & $\begin{array}{c}\text { RR kelompok dengan } \\
\text { demam intrapartum } \\
\text { (DI) }\end{array}$ & $\begin{array}{c}\text { RR kelompok } \\
\text { dengan KPD yang } \\
\text { disertai DI }\end{array}$ \\
\hline Usia kehamilan (minggu) & & & \\
$\geq 37$ & $1,12(0,44-2,86)$ & $3,62(1,43-8,23)$ & $4,23(1,31-19,8)$ \\
$<37$ RR-MH & $2,80(1,22-6,43)$ & $4,39(1,64-10,5)$ & $6,49(2,22-24,4)$ \\
& $1,70(0,67-4,07)$ & $3,97(1,91-8,11)$ & $5,17(2,13-11,3)$ \\
\hline Berat lahir (gram) & & & \\
$\geq 2500$ & $1,33(0,57-3,84)$ & $3,85(1,35-8,76)$ & $5,34(1,94-13,2)$ \\
$<2500$ & $2,57(1,16-4,87)$ & $4,20(1,83-12,5)$ & $5,50(2,23-14,1)$ \\
RR-MH & $1,73(0,80-4,01)$ & $4,00(2,10-7,76)$ & $5,41(2,42-10,9)$ \\
\hline
\end{tabular}


masing kelompok paparan (Tabel 2) menunjukkan $10(5,3 \%)$ neonatus yang lahir dari ibu dengan ketuban pecah dini (RR 1,76; IK 95\% 0,71-4,37); 6 $(12,8 \%)$ neonatus yang lahir dari ibu dengan demam intrapartum (RR 4,26; IK 95\% 1,55-11,7); 4 (12,9\%) dari 31 neonatus neonatus yang lahir dari ibu dengan ketuban pecah dini yang disertai demam intrapartum berkembang menjadi sepsis onset dini (RR 4,31; IK 95\% 1,38-13,5).

Analisis stratifikasi (Tabel 3) berdasarkan maturitas kehamilan dan berat badan lahir menunjukkan bahwa risiko sepsis onset dini neonatus yang terpapar ketuban pecah dini hanya meningkat secara bermakna pada kelompok neonatus kurang bulan dan/atau berat badan lahir rendah, tidak pada kelompok cukup bulan dan/ atau berat badan lahir cukup. Sementara risiko sepsis onset dini neonatus yang terpapar demam intrapartum dengan ataupun tanpa disertai ketuban pecah dini meningkat secara bermakna baik pada kelompok berat badan lahir cukup dan/atau cukup bulan maupun berat badan lahir rendah dan/atau kurang bulan. Penghitungan RR gabungan menggunakan statistik Mantel-Haenszel menunjukkan hasil yang tidak berbeda dengan penghitungan RR tanpa stratifikasi pada masing-masing kelompok paparan.

Angka biakan positif dijumpai pada $43,8 \%$ kasus. Penyebab utama patogen yang terisolasi adalah Escherichia coli (32\%), diikuti oleh Pseudomonas sp (25\%), Streptococcus sp (14,3\%), dan Staphylococcus epidermidis (14,3\%).

\section{Diskusi}

Beberapa penelitian mengenai faktor risiko sepsis onset dini telah dilakukan di berbagai negara. Sebagian besar hasil penelitian retrospekstif menunjukkan bahwa faktor-faktor maternal yang memegang peran penting adalah ketuban pecah dini, demam intrapartum dan korioamnionitis. $^{7-9}$ Pada penelitian prospektif kami, ketuban pecah dini tidak terbukti meningkatkan risiko secara bermakna. Hasil yang hampir sama dilaporkan oleh Schuchat $\mathrm{dkk}^{10}$ bahwa risiko neonatus yang terpapar ketuban pecah dini tidak meningkat secara bermakna pada kasus sepsis onset dini dengan etiologi yang bukan Streptococcus grup B. Hasil penelitian ini juga menunjukkan demam intrapartum dengan ataupun tanpa ketuban pecah dini berhubungan dengan peningkatan risiko lebih dari empat kali.
Korioamnionitis sengaja tidak dimasukkan sebagai variabel prediktor yang turut dinilai dalam penelitian ini, oleh karena demam intrapartum merupakan tanda klinis utama dari korioamnionitis yang pembuktian diagnosisnya sulit untuk dilakukan. ${ }^{14}$

Aldair $\mathrm{dkk}^{9}$ menemukan bahwa prematuritas merupakan faktor penting terhadap peningkatan risiko sepsis onset dini dengan penyebab kuman Streptococcus grup B. Pada penelitian lain dikatakan bahwa peningkatan risiko akibat prematuritas lebih tampak jelas pada kasus dengan etiologi SGB dibandingkan dengan kasus non-SGB. ${ }^{10}$ Untuk menyingkirkan kemungkinan maturitas kehamilan dan berat badan lahir sebagai variabel perancu dilakukan analisis stratifikasi berdasarkan variabel tersebut. Penghitungan risiko relatif ketuban pecah dini menggunakan statistik Mantel-Haenszel didapatkan hasil yang hampir sama dibandingkan penghitungan tanpa stratifikasi. Chacko \& Sohi ${ }^{4}$ melaporkan bahwa insidens sepsis onset dini pada neonatus dengan prematuritas dan berat badan lahir rendah tidak meningkat secara bermakna jika tidak disertai dengan faktor maternal. Namun demikian, hasil stratifikasi menunjukkan bahwa paparan ketuban pecah dini tidak terbukti meningkatkan risiko sepsis onset dini pada neonatus cukup bulan dan/atau berat badan lahir cukup secara bermakna. Sebaliknya risiko akan makin meningkat secara bermakna pada neonatus kurang bulan dan/atau berat badan lahir rendah yang terpapar ketuban pecah dini. Hal ini sesuai dengan beberapa laporan studi yang menunjukkan risiko infeksi cairan amnion meningkat secara bermakna pada neonatus dengan prematuritas yang disertai ketuban pecah dini. ${ }^{15}$

Penghitungan risiko relatif demam intrapartum dengan ataupun tanpa ketuban pecah dini menggunakan statistik Mantel-Haenszel pada stratifikasi berdasarkan maturitas kehamilan dan berat badan lahir didapatkan hasil yang hampir sama dibandingkan penghitungan tanpa stratifikasi. Hal ini menunjukkan bahwa pengaruh prematuritas dan berat badan lahir rendah pada penelitian kami tanpa disertai dengan faktor risiko maternal seperti ketuban pecah dini dapat diabaikan. Hasil yang sama juga dilaporkan pada penelitian sepsis onset dini di Pakistan, dengan simpulan bahwa prematuritas tidak dapat menjadi faktor risiko tunggal sepsis onset dini. ${ }^{6}$ Meskipun demikian, risiko neonatus yang terpapar demam intrapartum maupun ketuban pecah dini yang disertai dengan demam intrapartum pada kelompok dengan 
prematuritas lebih tinggi dibandingkan dengan kelompok neonatus cukup bulan. Hasil tersebut menunjukkan pengaruh prematuritas dan berat badan lahir rendah sebagai pengubah efek (effect modifier) pada neonatus yang terpapar ketuban pecah dan/atau demam intrapartum.

Proporsi biakan positif hanya terjadi pada $43,8 \%$ kasus, hampir sama dengan penelitian di negara berkembang lainnya dengan kisaran $41,7 \%$ sampai 47,5\% . ${ }^{16,17}$ Escherichia coli merupakan patogen utama $(32 \%)$, sama dengan hasil penelitian yang dilaporkan oleh Tallur dkk dan penelitian di negara berkembang yang lain, diikuti oleh Pseudomonas sp dan Streptococcus sp. ${ }^{18}$ Pada penelitian kami, 7 dari 9 kasus $(77,8 \%)$ sepsis dengan penyebab E. coli merupakan neonatus dengan berat badan lahir rendah menyiratkan bahwa E. coli merupakan penyebab utama sepsis onset dini pada neonatus dengan berat badan lahir rendah dan sangat rendah, diikuti oleh Streptococcus grup B. ${ }^{19}$

\section{Kesimpulan}

Demam intrapartum merupakan faktor risiko independen sepsis onset dini, sementara ketuban pecah dini hanya meningkatkan risiko secara bermakna pada kelompok neonatus kurang bulan dan berat badan lahir rendah. Meskipun demikian, skrining sepsis onset dini hanya diperlukan pada neonatus yang membawa faktor risiko maternal (ketuban pecah dini dan/atau demam intrapartum), sekalipun pada kelompok risiko tinggi yang berhubungan dengan prematuritas dan berat badan lahir rendah.

\section{Daftar Pustaka}

1. Gotoff SP. Neonatal sepsis and meningitis. Dalam: Behrman RE,. Kliegman RM, Nelson WE, Vaughan VC, penyunting. Nelson textbook of pediatrics. Edisi ke-15. Philadelphia: Saunders; 1996. h. 528-30.

2. Bhaumik S, Ghosh S, Haldar KK. Risk of early onset neonatal septicemia in babies born to mother with preeclampsia. Indian Pediatrics 2000;37:775-9.

3. Stoll BJ. Infections of the neonatal infant. Dalam: Behrman RE, Kliegman RM, Nelson WE, Jenson HB, penyunting. Nelson textbook of pediatrics. Edisi ke-16. Philadelphia: Saunders; 2004. h. 623-40.
4. Chacko B, Sohi I. Early onset neonatal sepsis, Indian J Pediatr 2005;72;23-6.

5. Remington JS. Bacterial sepsis and meningitis, dalam J.S. Remington, J.O. Klein: Infectious Disease of the Fetus and Newborn Infant, Edisi ke-5. Philadelphia: WB Saunders; 2001. h. 602-21,

6. Bhutta ZA, Yusuf K. Early-onset neonatal sepsis in Pakistan: a case control study in a birth cohort, Am J Perinatol 1997;14:577-81

7. Oddie S, Embleton ND. Risk factor for early onset neonatal group B streptococcal sepsis: case control study. BMJ 2002;325:308-11

8. Benitz EB, Gould JB, Druzin ML. Risk Factors for earlyonset Group B streptococcal Sepsis: Estimation of odds ratio by critical literature review. Pediatrics 1999;103:114

9. Aldair CL, Kowalsky L, Quon H. Risk factor for early-onset Group B streptococcal disease in neonates; a population-based case-control study. CMAJ 2003; 169:198-203

10. Schuchat A, Zywicki SS, Dinsmoor MJ. Risk factors and opportunities for prevention or early-onset neonatal sepsis: A multicenter case-control study. Pediatr 2000; 105:21-6

11. Surjono A. Pencegahan dan pengobatan terhadap infeksi pada neonatus, dalam Kumpulan makalah reuni dokter spesialis anak ke II FK UGM RSUP Dr.Sadjito, Yogyakarta, 1992

12. Yancey MK, Duff P, Kubilis P, Clark P, Frentzen BH. Risk factors for neonatal sepsis. Obstet Gynecol 1996; 87:188-94

13. McLaren RA, Chauhan SP, Gross TL. Intrapartum factors in early-onset group B streptococcal sepsis in term neonates: a case-control study. Am J Obstet Gynecol 1998; 174:1934-40

14. Petrova A, Demissie K, Rhoads GG, Simulian JC, Marcella S, dkk. Association of maternal fever during labor with neonatal dan infant morbidity and mortality. Obstet Gynecol 2001;98:20-7

15. Romero R, Tinnakorn, Chaiworapongsa. Preterm labor, intrauterine infection, dan the fetal inflammatory response syndrome, NeoReviews 2002;3:e73-e84

16. Kuruvilla KA, Pillai S, Jesudasan M, Jana AK. Bacterial profile of sepsis in a Neonatal Unit in South India. Indian J Pediatr 1998;35:851-58

17. Tallur SS, Kasturi AV, Nadgir SD, Khrisna BVS. Clinicobacteriological study of neonatal septicemia in Hubli. Indian J Pediatr 2000;67:169-74

18. Anwar SK, Mustafa S, Pariyani S, Ashraf S, Taufiq KM. 
Naufal Sastra Negara dkk: Ketuban pecah dini dan demam intrapartum sebagai faktor risiko sepsis neonatorum onset dini

Neonatal sepsis: an etiological study. J Pak Med Assoc 2000;50:91-4

19. Stoll BJ, Hansen N, Fanaroff AA, Wrigth LL, Carlo
WA. Changes in pathogens causing early-anset sepsis in very-low-birth-weight infants. N Engl J Med 2002; 347:240-7. 